\title{
Kimmeridgian hardground-sequence boundary from the Mesozoic margin of the Holy Cross Mountains (central Poland): implications for the evolution of the northern Tethyan carbonate shelf
}

\author{
Marcin Krajewski $^{1} \cdot$ Piotr Olchowy $^{1}\left(\right.$ Michał Zaton $^{2} \cdot$ Tomasz Bajda $^{1}$
}

Received: 9 January 2017 / Accepted: 1 April 2017 / Published online: 18 April 2017

(C) The Author(s) 2017. This article is an open access publication

\begin{abstract}
The sedimentary succession in central Poland records significant changes in facies at the turn of the Planula and Platynota zones in the Upper Jurassic, expressed by the drowning of the ramp-type platform and development of an extensive isochronous marl horizon. The topmost level of the marl horizon is a regional hardground, which is interpreted as the third-order sequence boundary Kim 1. In some areas, the hardground was eroded and is only preserved as bored and encrusted clasts. The composition of the borings may indicate that colonization and recolonization of the clasts took place in an extremely shallow water environment. The overall low level diversity of clastencrusting organisms and their occurrence on both sides of clasts indicates frequent overturning and high current activity. However, other extrinsic factors, such as salinity fluctuations, may have been involved. The final redeposition and burial of the clasts were related to subsidence through widespread reactivation of Paleozoic faults. Comparison with Middle Oxfordian-Lower Kimmeridgian sequences of central and southern Poland indicates that the carbonate ramp morphology and paleoenvironmental conditions were periodically subjected to significant modification during phases of extensional tectonics, with the development of fault-controlled intra-platform ridges and basins. These features may have been the NE continuation of parallel swells
\end{abstract}

Piotr Olchowy

piotrolch@geol.agh.edu.pl

1 AGH University of Science and Technology, Faculty of Geology, Geophysics and Environmental Protection, Al. Mickiewicza 30, 30-059 Kraków, Poland

2 University of Silesia, Faculty of Earth Sciences, Będzińska 60, 41-200 Sosnowiec, Poland and basins developed in the southern part of the carbonate platform adjacent to the Tethys.

Keywords Hardground · Borings · Encrustations ·

Synsedimentary tectonics - Seismites - Platform evolution . Late Jurassic · Poland

\section{Introduction}

Carbonate platform development on the northern Tethys shelf in central and southern Poland (Fig. 1) during the Late Jurassic was controlled mainly by sea-level and climate changes, the mosaic architecture of the Paleozoic basement and synsedimentary tectonics (e.g., Kutek 1994; Matyszkiewicz et al. 2012, 2016; Gutowski et al. 2005; Krajewski et al. 2011a, 2016). On a larger scale, these factors were related to Late Jurassic reactivation of older faults at the margins of the Paleozoic terranes forming the margin of the West European Platform near the Teisseyre-Tornquist Zone (Fig. 1). Three main transgressive-regressive tectono-stratigraphic units (Kutek 1994) or megasequences (Gutowski et al. 2005) have been distinguished to date, encompassing a succession beginning with transgressive, terrigenous Callovian facies and continuing to Purbeck-type Beriassian-Valanginian facies attaining ca. $1300 \mathrm{~m}$ in thickness (e.g., Kutek 1994; Gutowski et al. 2005; Krajewski et al. 2011a, b). The Upper Jurassic deposits of the studied Sobków area belong to the lowermost tectono-stratigraphic unit embracing the Callovian-Lower Kimmeridgian (Hypselocyclum Zone) deposits. Kutek (1994) divided this unit into two parts whose development was connected to two successive but distinct tectonic regimes (Fig. 2): interval I, which encompasses the Callovian-Oxfordian (including the Planula Zone), and interval II, which encompasses the 


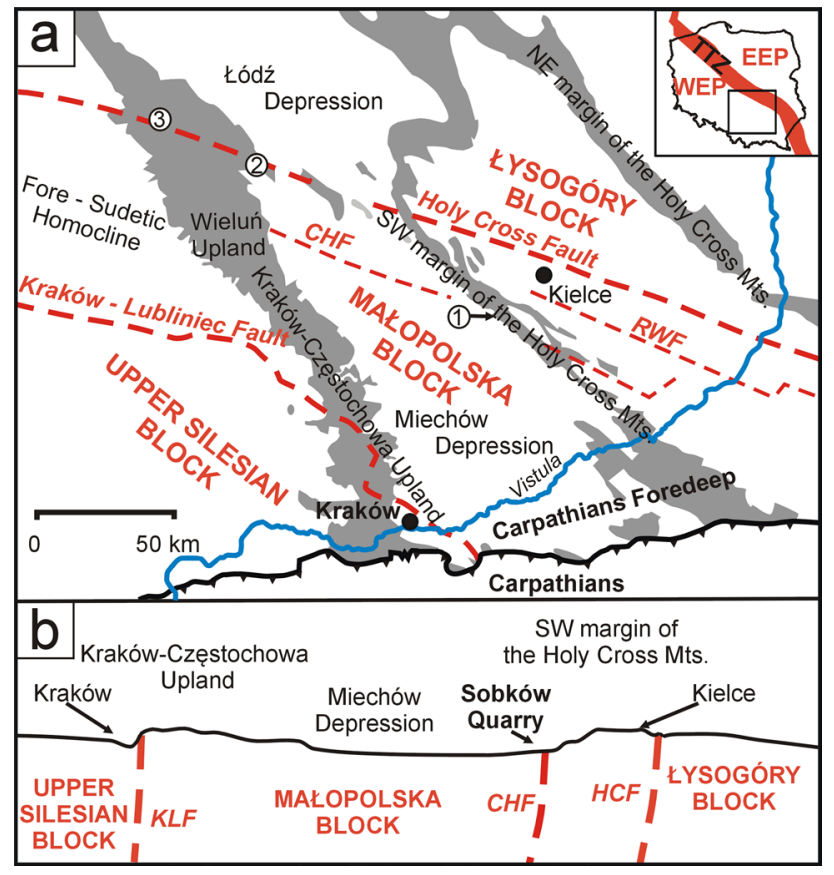

Fig. 1 a Location map of the study areas with Upper Jurassic outcrops and sub-Cenozoic Jurassic subcrops (grey) in southern and central Poland [after Pożaryski et al. (1979), modified and simplified]. Tectonic structures (red) after Zelazniewicz et al. (2011). CHF Chmielnik Fault, $R W F$ Ryszkowa Wola Fault, $K L F$ Kraków-Lubliniec Fault, HCF Holy Cross Fault, TTZ Teisseyre-Tornquist Zone, EEP East European Platform, WEP West European Platform. 1 Sobków area, 2 Bełchatów area, 3 Złoczew area. b Sketch of main geographical units and main tectonic units in the Paleozoic basement

Lower Kimmeridgian (Platynota-Hypselocyclum zones). In the Submediterranean subdivision, the Planula Zone, though coeval with the Lower Kimmeridgian of the Boreal province, is traditionally confined to the Upper Oxfordian. Both intervals are divided by an isochronous marker horizon, the so-called Lowermost Marly Horizon, included in the Lower Platynota Zone (Fig. 2). This marker horizon is of key significance in stratigraphic correlation of Upper Jurassic deposits in central and southern Poland (Kutek 1994). At the break between intervals I and II, significant changes in facies occurred in the Polish part of the northern peri-Tethyan shelf (Fig. 2; e.g., Kutek 1994; Matyszkiewicz 1996; Krajewski et al. 2016). These changes were marked by: (i) the disappearance of microbial-sponge, microbial-Crescentiella, and coral buildups characteristic of the Upper Oxfordian; (ii) drowning of the platform in the Lower Platynota Zone and development of marly facies, and (iii) common occurrence of gravity-flow deposits in the form of debrites, conglomerates, calciturbidites, and olistoliths.

In central Poland, the next sedimentary sequence (interval II) is represented mainly by Lower

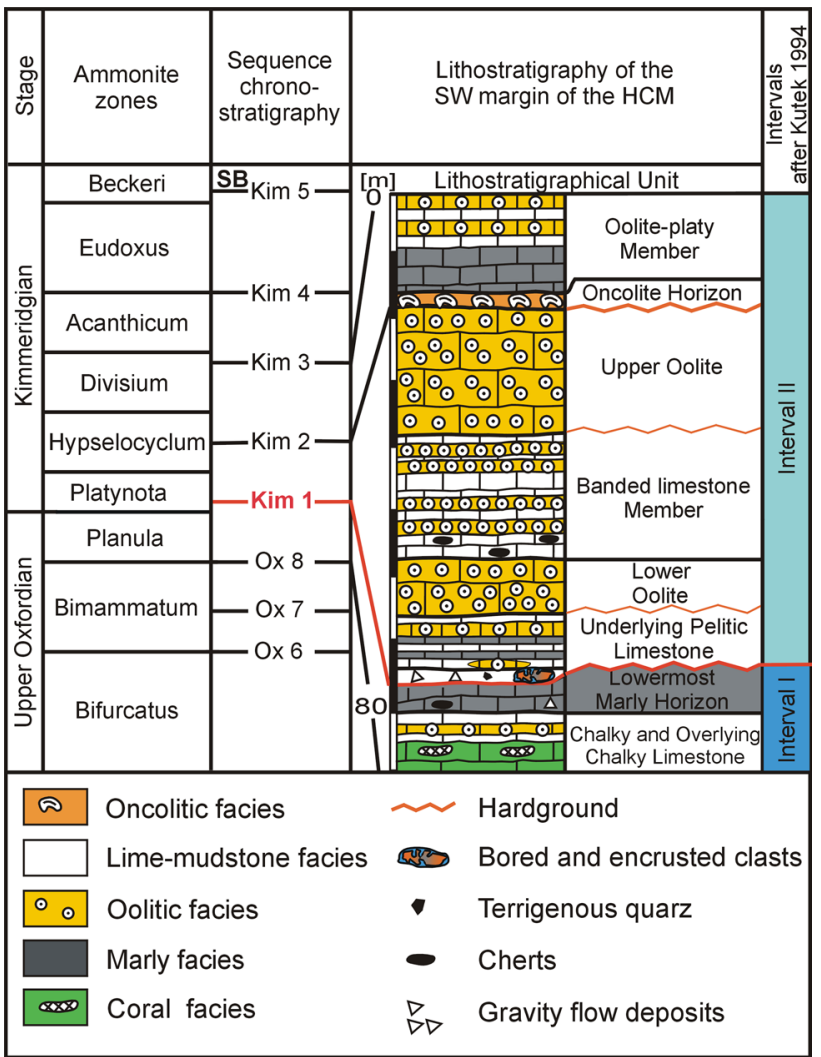

Fig. 2 Stratigraphy and lithology of the Upper Oxfordian-Lower Kimmeridgian deposits from the SW margin of the Holy Cross Mts. [modified after Kutek et al. (1992)]. Ages of ammonite subzone boundaries and of sequence boundaries (SB) according to Hardenbol et al. (1998)

Kimmeridgian (Platynota-Hypselocyclum zones) oolitic and oncolitic facies with common hardgrounds (Fig. 2; e.g., Kaźmierczak and Pszczółkowski 1968; Goldring and Kaźmierczak 1974; Gruszczyński 1986). To date, the succession from the turn of the Planula and Platynota zones has not been fully documented with respect to facies, making it difficult to establish the sequence boundary dividing the two intervals representing different stages of carbonate platform evolution in this Polish part of the northern Tethys shelf.

The main aims of the present work are: (i) to present new data concerning the lower Kimmeridgian succession from Sobków quarry and characteristics of the sequence boundary between Kutek's (1994) intervals I and II, (ii) to elaborate and present new data on burrows, borings, and encrustations developed in hardground and clasts, (iii) to present chemical analyses and stable isotopes of $\mathrm{O}$ and $\mathrm{C}$ from the clasts, and (iv) to discuss the results obtained in the context of reconstructing the evolution of the Polish part of the Upper Jurassic carbonate platform in the northern Tethys shelf. 


\section{Geological background}

The investigated Upper Jurassic deposits from Sobków quarry (in the Sobków village) are located in the so-called southwestern Mesozoic border of the Holy Cross Mountains in the vicinity of its junction with the Miechów Depression (Fig. 1). In this area, the Jurassic deposits are well exposed in numerous sites; however, towards the south, they are covered by Upper Cretaceous deposits (e.g., Jurkowska 2016). The succession in the area comprises Callovian-Upper Kimmeridgian deposits representing outer, middle, and inner carbonate ramp-type platform facies (e.g., Kutek 1968, 1969; Kutek et al. 1992; Matyja et al. 1989; Matyja 2011). In the vicinity of Sobków quarry, the Upper Jurassic section starts with so-called Siedlce Limestone (Matyja et al. 1989), mainly composed of fine-grained limestone (wackestone) and lime mudstone (mudstone). Higher up, the deposits reach tens of meters in thickness and encompass several regional lithostratigraphical units (Fig. 2). The so-called Chalky Limestone unit ( $\sim 35 \mathrm{~m}$ thick) is formed of bioclastic limestone with bivalves, gastropods, colonial corals, and algae (Matyja et al. 1989). The next unit, Overlying Chalky Limestone ( $10 \mathrm{~m}$ thick), is represented by thick- and thin-bedded limestone, oolitic limestone and marl. These are overlain by the Lowermost Marly Horizon ( $4 \mathrm{~m}$ thick), composed of marl with thin intercalations of marl and fine-grained marly limestone and lime mudstone. At the top of this horizon, a $20-\mathrm{cm}$ bed of laminated, fine-grained limestone with a regional hardground is observed (e.g., Gruszczyński 1986, Matyja 2011; Fig. 2), along with its eroded fragments in the form of prolifically bored and encrusted clasts forming a characteristic layer (Chudzikiewicz and Wieczorek 1985). Above, the Underlying Pelitic Limestone unit $(\sim 10 \mathrm{~m}$ thick), represented by fine-grained bioclastic limestone, lime mudstone, and marl intercalated with bioclastic and ooid laminae, is overlain by the Lower Oolite unit $(\sim 10 \mathrm{~m}$ thick) composed of oolitic-bioclastic limestone. All of these units represent the Planula and Platynota zones.

\section{Materials and methods}

This research is mainly based on field observations in Sobków quarry and the sample collection housed at the Institute of Geological Sciences of the Polish Academy of Sciences in Kraków, abbreviated ZNG PAN A-V-84. The archival photographs and rock samples previously used by Chudzikiewicz and Wieczorek (1985), as well as new samples, were examined in the present study. Observations of the Lowermost Marly Horizon with its hardground were carried out in wells in the Złoczew and Bełchatów areas (Krajewski et al. 2014; Fig. 1). Also, some additional information on the hardground described in this paper was taken from papers concerning outcrops in the so-called Mesozoic southwestern border of the Holy Cross Mountains (e.g., Gruszczyński 1986; Matyja 2011). For macro- and microscopic studies, polished slabs and thinsections were prepared from both carbonate clasts and host sediment.

The samples were characterized using variable pressure field-emission scanning electron microscope (FEI Quanta 200 FEG) equipped with an energy dispersive spectrometer (EDS). Data were collected from the red and grey parts of the clasts and the matrix of the clast-bearing host deposit (Table 1).

Stable carbon and oxygen isotopes of samples from Sobków quarry were determined (22 samples from red parts of the clasts, 21 from grey parts). Where possible, bioclasts were omitted during the sampling. Carbonate powders were reacted with $100 \%$ phosphoric acid at $70{ }^{\circ} \mathrm{C}$ using a GasBench II device connected to a ThermoFisher DELTA V Plus mass spectrometer. All
Table $1 \mathrm{SiO}_{2}, \mathrm{Fe}_{2} \mathrm{O}_{3}$, and $\mathrm{CaCO}_{3}$ contents in the clasts and the matrix of the layer

\begin{tabular}{lcccc}
\hline Layer with bored and encrusted clasts & Sample & $\mathrm{SiO}_{2}(\%)$ & $\mathrm{Fe}_{2} \mathrm{O}_{3}(\%)$ & $\mathrm{CaCO}_{3}(\%)$ \\
\hline Red part of the clast & 1 & 6.18 & 3.09 & 89.06 \\
& 2 & 8.87 & 3.90 & 82.99 \\
& 3 & 5.57 & 10.31 & 81.62 \\
Grey part of the clast & 4 & 4.95 & 3.76 & 88.40 \\
& 5 & 8.46 & 0.99 & 86.03 \\
& 6 & 8.12 & 0.93 & 86.33 \\
Matrix of the layer & 7 & 9.55 & 1.11 & 84.26 \\
& 8 & 8.11 & 0.92 & 87.38 \\
& 9 & 8.86 & $<0.10$ & 87.44 \\
& 10 & 3.83 & $<0.10$ & 93.84 \\
& 11 & 4.92 & 1.06 & 90.82 \\
& 12 & 4.96 & 0.72 & 90.94
\end{tabular}


measured values were reported in per mil relative to V-PDB standards. The level of measurement precision was higher than $\pm 0.1 \%$ o for both carbon and oxygen isotopes.

\section{Results}

\section{Sedimentary succession in the NE part of Sobków quarry}

Currently, the lowermost part of the section at Sobków quarry is partly covered by rubble, although it was visible here in the 1980s (Fig. 3a, b). The succession in the NE part of Sobków quarry begins with deposits belonging to the Lowermost Marly Horizon (Figs. 3a, 4), represented by marl and finely laminated microbioclastic limestone. In sections of the uppermost part of the Lowermost Marly Horizon, the bored and encrusted hardground (Fig. 3b) formed of finely laminated bioclastic wackestone is exposed.

These deposits are overlain by a limestone layer up to $0.8 \mathrm{~m}$ thick, divided into lower and upper parts by an erosional surface (Fig. 3a, b). The characteristic features of the layer (both lower and upper parts) are: (i) numerous clasts, (ii) an erosional contact at the base, (iii) a coarser-grained lower part and mostly finer-grained upper part, and (iv) local clast imbrication and a chaotic arrangement of bivalve shells (Fig. 3c).

The lower part of the layer is composed of yellow-red limestone, 0.3-0.4 m thick, with numerous clasts locally forming conglomerates (Figs. 3c, 4, 5). Among the clasts (see below for details), heavily bored and encrusted, redbrownish, dark greyish-yellow and grey clasts dominate (Fig. 5). The quantity of clasts in this part of the layer decreases upward. The matrix of this part of the layer consists of bioclastic wackestone-floatstone with skeletal and non-skeletal grains (Figs. 5a, e, 6a). Among the bioclasts, gastropods, oysters, non-ostreid bivalves, echinoids and serpulids dominate. The longer axis of bivalve shells have variable orientations. Non-skeletal grains consist of ooids and oncoids, as well as terrigenous quartz. Above the erosional surface there is bioclastic floatstone with grey, discoidal clasts devoid of borings representing base of the upper part of the layer (Figs. 3a, $4)$. The number of grains in the upper part of the layer decreases upward with bioclastic wackestone passing up into lime mudstone (Fig. 4). Above, thin-bedded marl and bioclastic limestone with oolitic-bioclastic limestone lenses occur (Fig. 4). These deposits represent the next unit, belonging to the so-called Underlying Pelitic Limestone, which passes up into bioclastic grainstone of the Lower Oolite (Fig. 2).

\section{Bored and encrusted clasts}

Morphology, size, and texture of the clasts

The size of the clasts ranges from several $\mathrm{mm}$ up to $20 \mathrm{~cm}$ in length and $9 \mathrm{~cm}$ in width (Figs. 3c, 5). The smallest clasts are subangular, well-rounded and irregularly distributed (Figs. 3c, 5a). Larger clasts are discoidal and have well-rounded margins (Fig. 5a, e, f). Commonly, one side of a clast is uneven, with numerous depressions and tapering cracks (Fig. 5c), whereas the other side is smooth or slightly wavy (Fig. 5f). Despite the color of the clasts, two lithological types can be distinguished. Clasts of type I are formed by finely laminated bioclastic wackestone-packstone (Fig. 6a-c), whereas those of type II, observed here for the first time, occurring more locally, are composed of coral framestone (Fig. 5b). Borings and encrustations are similar in both clast types.

\section{Color differentiation of the clasts}

One characteristic feature of the clasts is the great differentiation in their color, which is related to the distribution of iron oxides (Figs. 5a, c, d, 6a-c; Table 1). The coloration within the clasts varies according to: (i) clast size; (ii) the matrix type of the clasts, and (iii) the density of the borings and cracks therein. Often, these different colors are observable within the same clast, in which case it is characterized by a colorful smudged appearance.

(i) Smaller clasts, less than $1 \mathrm{~cm}$ in size, are in the majority of cases grey-yellow or red-brown (Figs. 5a, f, 6a). In larger clasts, $1-20 \mathrm{~cm}$ in size and characterized by a homogenous matrix, the centers are grey (Fig. 5a, f, h). Toward their outer parts, the color gradually changes to grey-yellow and red-brown, commonly forming characteristic thin (from several $\mathrm{mm}$ to $0.5 \mathrm{~cm}$ thick) rims on the outer surface of the clasts. Irregular red oxidative stains with non-sharp boundaries, ca $1.5 \mathrm{~cm}$ in diameter, are also observed (Fig. 5h).

(ii) Fragments of the clasts composed of fine packstone are usually more distinctly grey than the fragments composed of bioclastic wackestone-packstone, which are more yellow or reddish in color (Fig. 5a, c, d).

(iii) Those parts of the clasts with a low density of borings and cracks possess additional thin (up to several mm thick) red-yellow aureoles around these structures, which gradually fade into the grey-colored matrix of the clasts (Figs. 5e, 6b, c). In cases where the density of borings and cracks is high, these zones are joined, forming a more homogenous, reddish-yellow color of the clasts (Fig. 5a, c, g). 
Fig. 3 Sedimentary succession from Sobków quarry. Archival photos by L. Chudzikiewicz. a In the lower part of the section, the so-called Lowermost Marly Horizon and Kim 1 SB are visible. The lower and upper part of the studied layer is visible in the central part; in the upper part, the next sequence is represented by the Underlying Pelitic Limestone. b Studied layer: below, laminated hardground with borings (white arrows); black arrows indicate the border between the lower and upper parts of the layer. c Details of the studied layer: in the central part, imbrication of the clasts and the junction between the lower and upper parts of the layer are visible (white arrows)
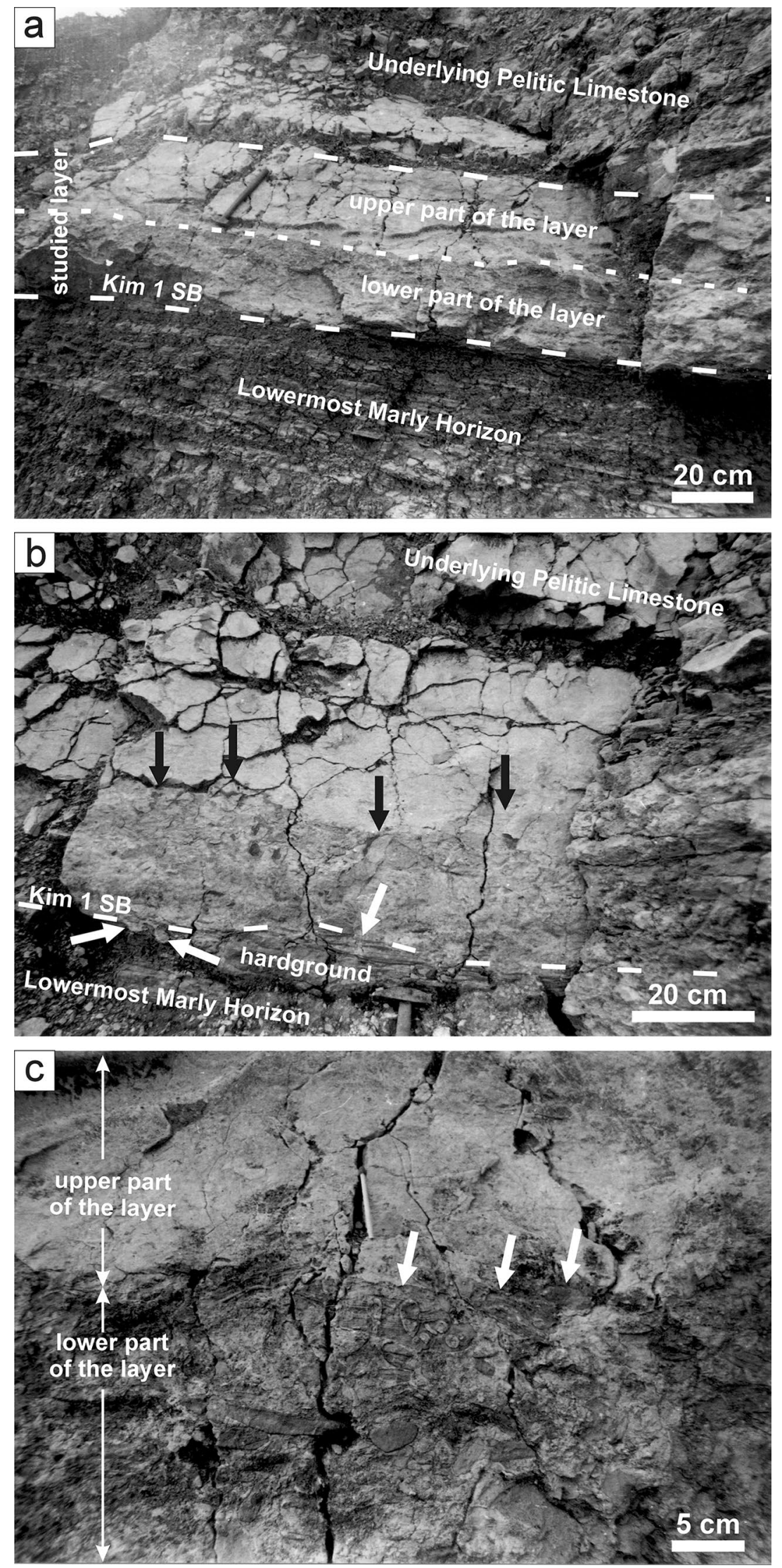


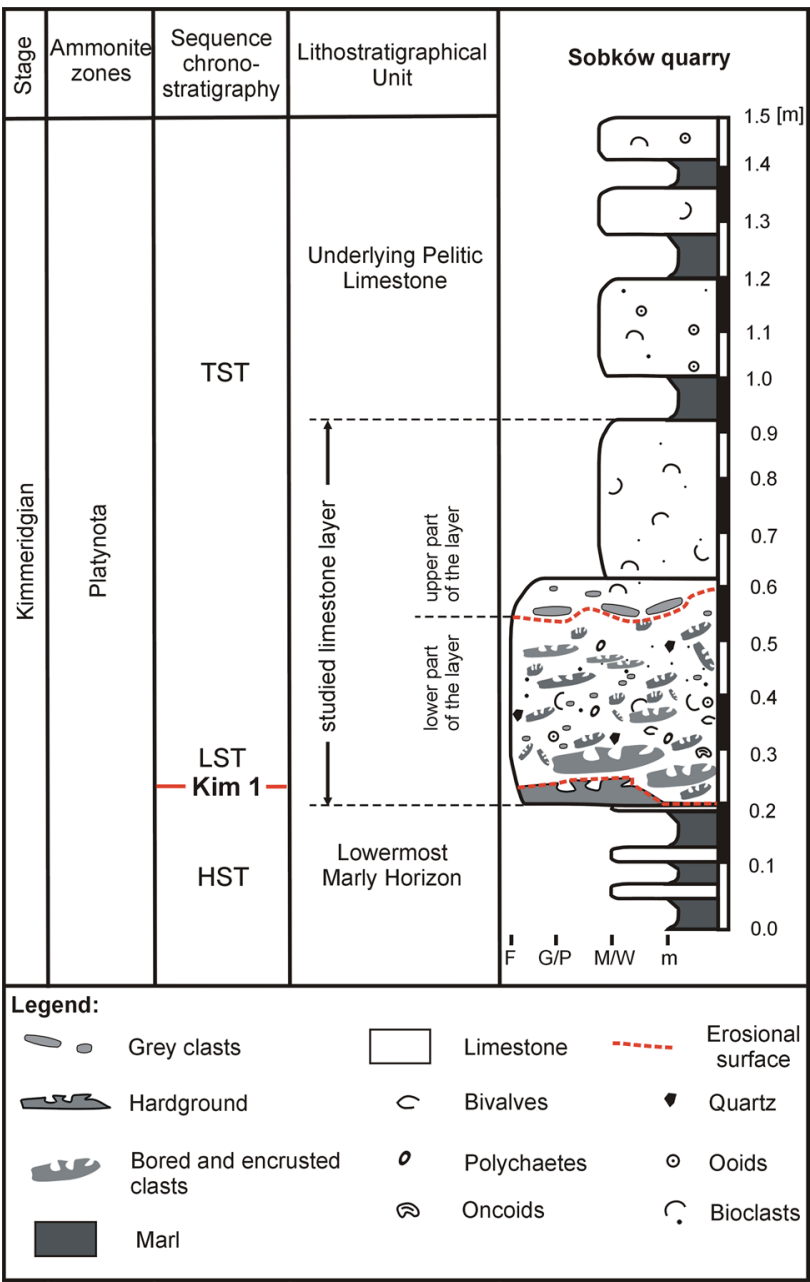

Fig. 4 Lithostratigraphic column of the NE part of Sobków quarry: $m$ marl, $M$ mudstone, $W$ wackestone, $F$ floatstone, $P$ packstone, $G$ grainstone. Kim 1-sequence boundary: TST transgressive systems tract, $H S T$ highstand systems tract, $L S T$ lowstand systems tract

\section{Borings and encrustations}

Two types of borings have been identified: Trypanites and Gastrochaenolites (Figs. 5, 6). Trypanites are thin, deep borings which might have been produced by worms such as polychaetes or sipunculids (e.g., Pemberton et al. 1980; Taylor and Wilson 2003; Bromley 2004). This type of boring is rare, having been observed in seven clasts. Clavate bivalve borings are much more common, having been observed in 17 clasts, and abundant in particular clasts (Figs. 5, 6). Taking the ichnotaxonomical scheme of Kelly and Bromley (1984) into account, the bivalve borings may represent three ichnospecies: $G$. cf. torpedo, $G$. cf. lapidicus and G. cf. cluniformis. In some borings, bivalve shells have also been noted within (Figs. 5c, e, $6 b)$. However, it is uncertain whether the shells belong to the borers or to later squatters. Both Gastrochaenolites and Trypanites are common borings in many Jurassic hard substrates (e.g., Gruszczyński 1986; Wilson and Palmer 1994; Taylor and Wilson 2003; Bromley 2004; Wilson et al. 2010; Zatoń et al. 2011a; Zatoń and Machalski 2013).

Encrusters (or epilithozoans sensu Taylor and Wilson 2002) are dominated by bivalves (Fig. 5c, d, g, h) and serpulid polychaetes (Figs. 5b, c, g, 6b), noted on 15 and 12 clasts, respectively, whereas cyclostome bryozoans appear more rarely (on one clast only). However, taking the incompleteness of the material into account, bryozoans, represented by small colonies, may occur on many more substrates. Bivalves, here represented exclusively as attached valves similar to small oysters, are very common in the Kimmeridgian deposits of Poland (e.g., Machalski 1998; Zatoń and Machalski 2013). The serpulid polychaetes are more diverse, represented by three types of tubes, which may be referred to as Cycloserpula, Glomerula (here G. gordialis), and Tetraserpula. These occur on the clast surface (Fig. 6b), but were also observed encrusting the inside of the Gastrochaenolites borings (Fig. 5d). These serpulids are a common constituent of many Jurassic hard substrate environments (Radwańska 2004; Zatoń et al. 2011a, b; Zatoń and Machalski 2013).

\section{Analytical results}

The SEM-EDS analyses showed variable $\mathrm{Fe}_{2} \mathrm{O}_{3}$ content in reddish and grey areas of the same clasts (Table 1; Fig. $6 \mathrm{e}, \mathrm{f}$ ); in the grey areas, it does not exceed $1.2 \%$ (or locally $0.1 \%$ ), whereas in the reddish areas it exceeds $3 \%$ and locally even $10 \%$ (Table 1).

Values of ${ }^{13} \mathrm{C}$ in the analyzed clasts range from 1.04 to $2.54 \%$; those of $\delta^{18} \mathrm{O}$ range from -4.15 to $-2.57 \%$ o. In the graph of the relationship between $\delta^{13} \mathrm{C}$ and $\delta^{18} \mathrm{O}$, two clouds of points are visible (Fig. 7). One includes the values of $\delta^{13} \mathrm{C}$ and $\delta^{18} \mathrm{O}$ from red parts of the clasts, the other from the grey parts of the clasts. In the first collection, the $\delta^{13} \mathrm{C}$ values are grouped in the range of $1.04-2.54 \%$ and $\delta^{18} \mathrm{O}$ values in the range of -4.15 to $-2.68 \%$; in the second, the points are included in the range of $2.03-2.43 \%$ o for $\delta^{13} \mathrm{C}$ and -3.08 to $-2.57 \%$ ofor $\delta^{18} \mathrm{O}$. A greater range of variability of $\delta^{13} \mathrm{C}$ and $\delta^{18} \mathrm{O}$ values in the red parts of the clasts (1.50 and $1.47 \%$ o, respectively) is observable in relation to the grey parts of the clasts, where the ranges of $\delta^{13} \mathrm{C}$ and $\delta^{18} \mathrm{O}$ variability are equal $(0.40$ and $0.51 \%$, respectively). Correlation of $\delta^{13} \mathrm{C}$ and $\delta^{18} \mathrm{O}$ values for samples taken from the red parts of the clasts is positive $(r=0.70)$. The values for the grey parts of the clasts, on the other hand, show no correlation $(r=0.10)$. 

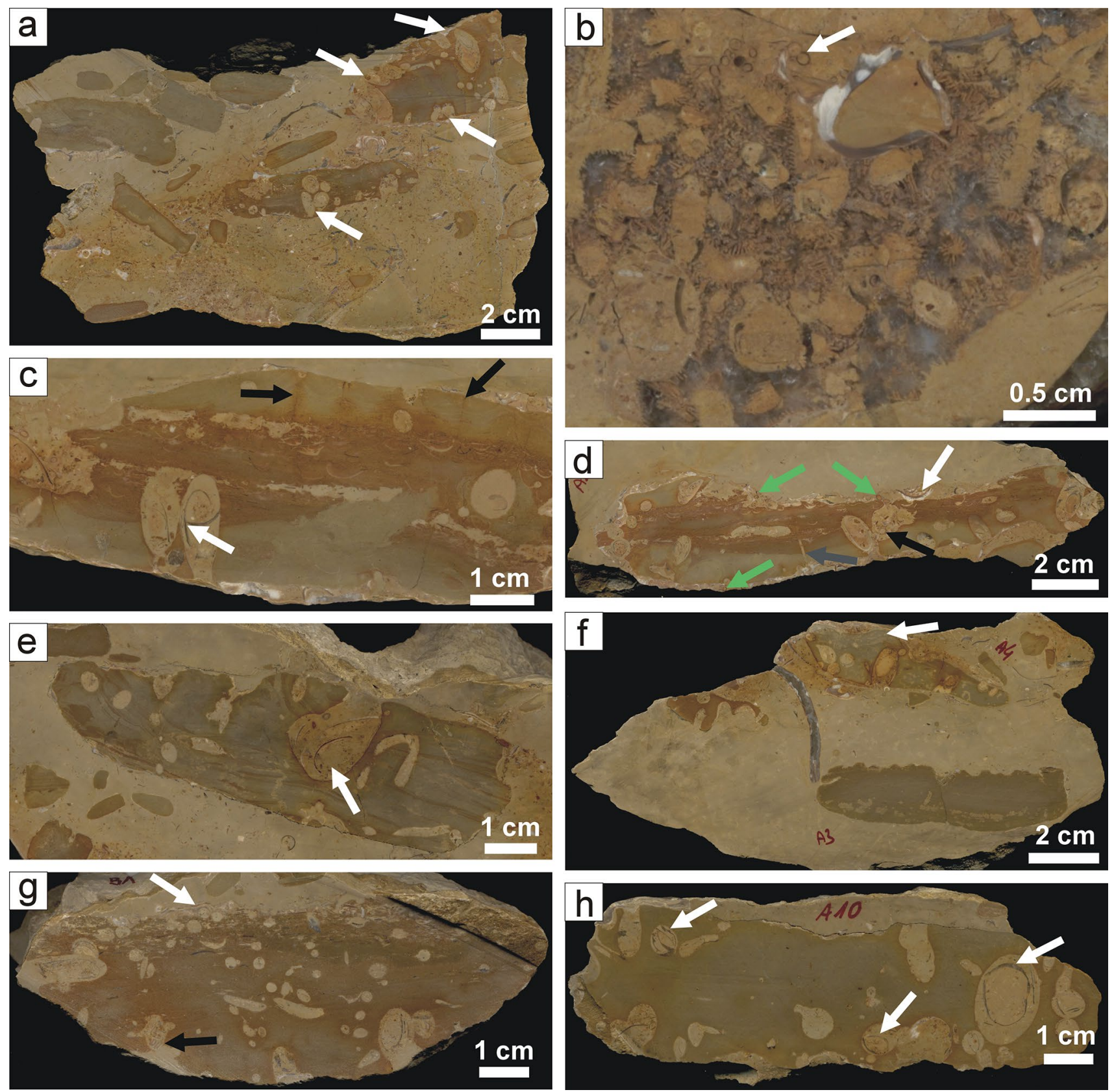

Fig. 5 Polished slabs from the layer with bored and encrusted clasts from Sobków quarry. a Floatstone with bored and encrusted type I clasts: in the upper part, imbrication of the clasts is visible; around clasts and borings, thin red aureoles are developed; the matrix of the layer consists of numerous chaotically distributed bivalves and other bioclasts; arrows point to bivalve borings (Gastrochaenolites). b Coral framestone: fragment of a bored clast of type II; in the upper part of the clast a serpulid tube in cross section is visible (arrow). c Floatstone: clasts with color-smudged features; red bioclastic wackestone in the central part of the clasts; grey fine packstone in the upper and lower parts of the clast; around borings and cracks red aureoles are presented; bivalve shell fragments within a Gastrochaenolites boring (white arrow); cracks (black arrows) in the upper part of the clast. d Floatstone: a clast with numerous Gastrochaenolites bor-

ings, encrusted by serpulids; cemented oyster valve (white arrow), serpulid tubes (green arrows), serpulids within an empty boring (black arrow); the grey arrow points to a Trypanites-like boring. e Floatstone: a clast with numerous bivalve borings; a large Gastrochaenolites with bivalve shell fragments inside (arrow). f Floatstone: grey clast of fine packstone with borings in the central part; the upper part of the clast is erosional, with numerous depressions, whereas the other side is smooth or slightly wavy; in the upper part, a clast with numerous Gastrochaenolites borings, encrusted by serpulids (arrow). g Floatstone: numerous Gastrochaenolites borings, encrusting oyster (white arrow) and serpulid tubes within a bivalve boring (black arrow). h Floatstone: a clast intensively bored by bivalves whose shell remains are still preserved within the borings (arrows) 

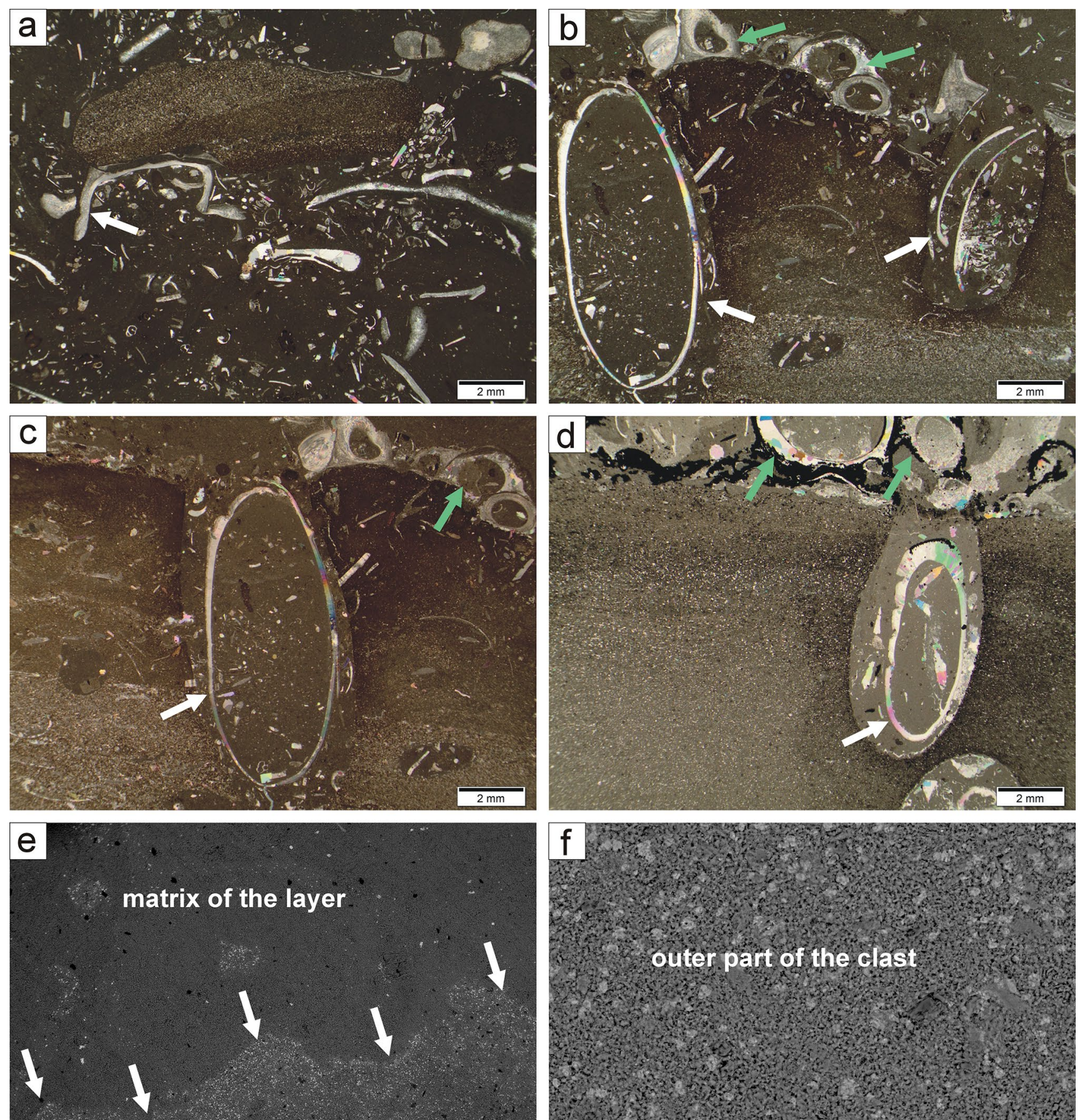

clast

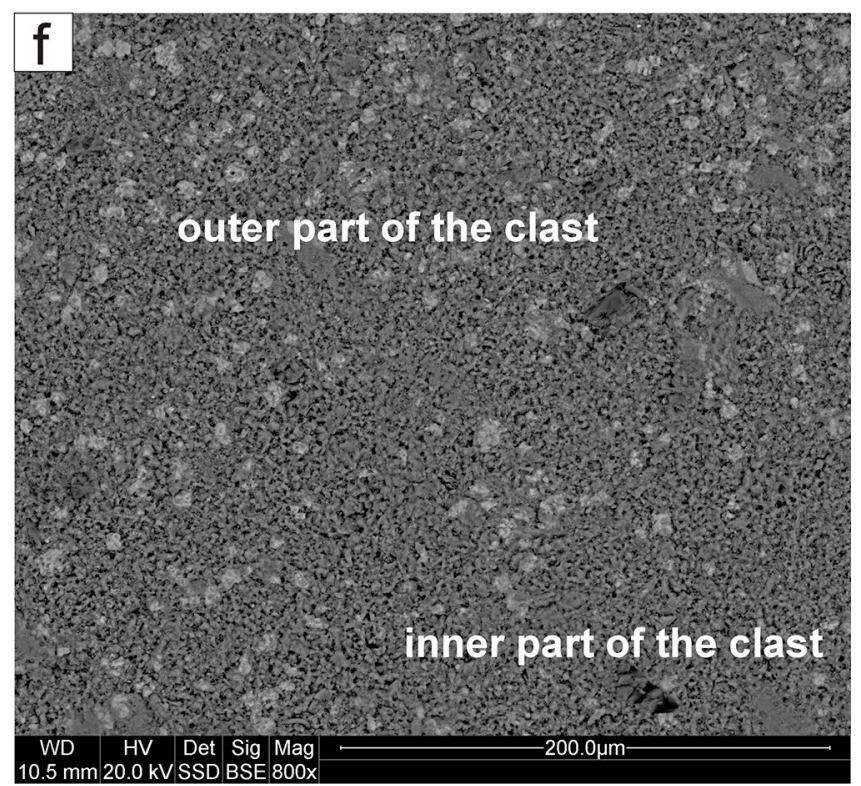


4Fig. 6 Microfacies observed in the layer with bored and encrusted clasts from Sobków and Bełchatów (d) areas. a Bioclastic floatstone with numerous bivalves and gastropods: brown-reddish laminated clasts of fine packstone in the central part. b Floatstone: fragment of clasts with bivalves in Gastrochaenolites borings (white arrows) and serpulids on the outer surface (green arrows); characteristic brownred aureoles visible around borings. c, d Clasts from Sobków (c) and Bełchatów (d) areas: serpulid tubes (green arrows) in the upper part of the photographs; in the lower part, fine packstone with bivalves are visible; around the borings, a characteristic aureole of ferriferous (c) and pyritized (d) sediment is present. The pyritized aureoles correspond very well to the brown-red-yellow ferriferous aureoles at the outer part of the clast and around borings. Gastrochaenolites borings with shells within clast (white arrows). e, f SEM images of the outer ferriferous part of the clast. The degree of ferruginous content gradually decreases in the central part of the clast. White arrows show the irregular outer edge of the clast

\section{Discussion}

Development of the Lowermost Marly Horizon in central Poland ended with the formation of a hardground in its uppermost part during a sea-level fall. At early stages, prior to the full lithification of the sediment forming the future hardground, the latter was intensively burrowed (Fig. 8).

In some areas of central Poland close to the main faults, the hardground was eroded and preserved as bored and encrusted clasts (Chudzikiewicz and Wieczorek 1985; Krajewski et al. 2014). The origin of these clasts was related to erosion of the hardground forming the type I clasts (Fig. 8). Locally, however, the hardground was covered by coral colonies, and these parts formed the type II clasts (Fig. 8). Destruction of the hardground may be related to the model described by Anketell et al. (1970). According to these authors, in a section in which an upper layer is characterized by brittle behavior, the disturbance resulting from liquefaction of the underlying soft marl layer may lead to the fracturing, fragmentation, and collapse of the hardground (Fig. 8). Clasts formed by this process have been described from the Kimmeridgian (Acanthicum Zone) deposits of Małogoszcz quarry, Central Poland, by Radwański (2003). This process might be related to seismic tremors, such that any breccias formed could be classified as seismites (e.g., Montenat et al. 2007). To date, bored and encrusted clasts in the uppermost part of the Lowermost Marly Horizon are known from the Złoczew, Bełchatów, and Sobków areas (Fig. 1). It is plausible that the environmental conditions prevailing during clast formation in these latter localities were similar, as evidenced by the presence of a similar matrix of layers, burrows, borings, and encrustations. However, some of the structural and geochemical features (stable isotopes of $\mathrm{O}$ and $\mathrm{C}$ ) noted in the Sobków clasts point to different diagenetic conditions, including shallowmarine sedimentation and the influence of meteoric waters (Figs. 7, 8, cf. Gruszczyński 1986).
Prior to final burial, the clasts were subjected to at least several phases of development (Fig. 8), including burial, submarine exhumation, redeposition, and recolonization by boring and encrusting organisms (Chudzikiewicz and Wieczorek 1985; Krajewski et al. 2014). Taking the complex developmental history of the clasts into account, it can be assumed that the preserved borings and encrusters represent time-averaged assemblages consisting of several generations of organisms, which colonized the clasts at different times and environments (in terms of depth) during their pre-final-burial history. With the possible exception of three ichnospecies of bivalve borings ( $G$. cf. torpedo, $G$. cf. lapidicus and G. cf. cluniformis) and one type of 'worm' boring (Trypanites), the encrusting assemblages noted on the clasts are not taxonomically diverse. Rather, they are dominated mainly by serpulid tubes and oyster bivalves, groups which are usually very common and most numerous on Jurassic hardgrounds in general (e.g., Fürsich 1979), whereas stenohaline taxa such as cyclostome bryozoans and crinoids are in the minority (see Chudzikiewicz and Wieczorek 1985). The crinoids are represented only by one holdfast, which in fact may have been originally attached earlier to the hardground itself and not to the hardgroundderived clasts. This may be supported by the observation of a similar holdfast on a hardground surface in the Upper Oolitic Limestone at Mieronice, $20 \mathrm{~km} \mathrm{NW}$ of Sobków (Chudzikiewicz and Wieczorek 1985). Thus, overall, the encrusting assemblages preserved on clasts are taxonomically impoverished, especially when compared to those encrusting other Jurassic hard substrates from normalmarine environments (e.g., Palmer and Fürsich 1974; Taylor 1979; Fürsich et al. 1994; Zatoń et al. 2011a, b). The question is whether such encrusting assemblages reflect restricted paleoenvironmental conditions or result from frequent overturning of the clasts in a dynamic paleoenvironment prior to their final burial. It is known that such extrinsic factors as fluctuations in productivity (e.g., Lescinsky et al. 2002) or salinity (e.g., Gruszczyński 1986; Wilson and Palmer 1994) may have an impact on the diversity of hard-substrate biotas. However, it is also evident that a low level of diversity of encrusters is observed on clasts which were subject to high levels of disturbance on the sea floor (Wilson 1985, 1987). In the present case, it is highly speculative to suggest that either of these factor(s) were responsible, especially given that the clasts underwent a long and complex pre-burial period during which they may have experienced several episodes of colonization and erosion.

The composition of the borings, and especially the domination of Gastrochaenolites, indicate that colonization of the clasts generally proceeded in a shallow-water environment (e.g., Bromley 1994; Wilson et al. 2012), where the hydrodynamics were strong enough to overturn the clasts, as evidenced by the borings and encrustations present on 


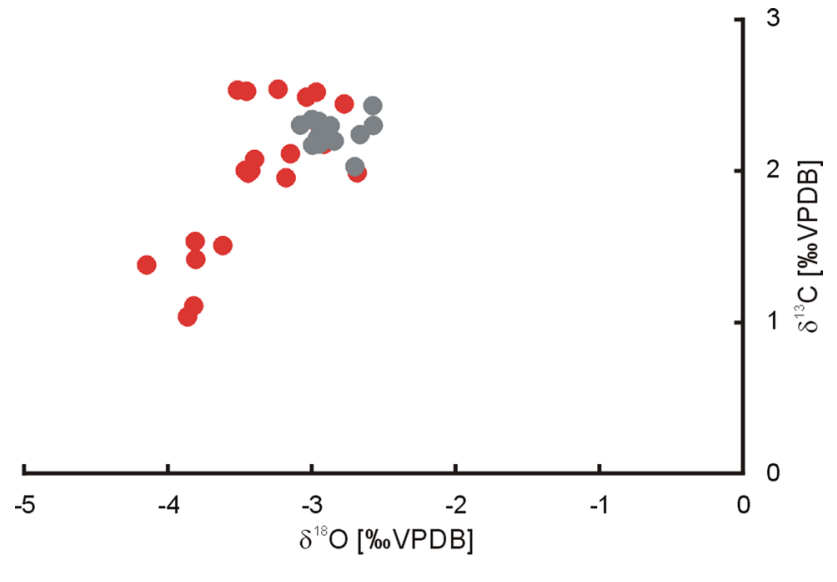

red part of the clast

grey part of the clast

Fig. 7 Distribution of $\delta^{13} \mathrm{C}$ and $\delta^{18} \mathrm{O}$ values in reddish and grey parts of the clasts

both sides of the clasts. Such shallow settings are also influenced by salinity fluctuations, reflected in the stable composition of isotopes and possibly as well in the low level of diversity of encrusters (see also Gruszczyński 1986).

Deposition of the clasts occurred in a shallow, subtidal environment, possibly often in restricted areas where gastropods, serpulids, and bivalves dominated. The ferruginous outer parts of the clasts and ferruginous oxidative spots, along with laminae and aureoles around the borings and cracks, could have been a consequence of surface oxidation of pyrite grains during weathering and reworking of the clasts on an oxygenated seafloor in extremely shallow water. It is possible that the ferruginated parts also resulted from liberation of $\mathrm{Fe}$ bound in the calcite structure or weathering of clay minerals (cf. Retallack 2001).

The paleoenvironmental conclusions presented above are supported by the $\mathrm{C}$ and $\mathrm{O}$ isotope signatures of the clasts (Fig. 7), which suggests that calcite precipitation proceeded under marine conditions for which values of $\delta^{13} \mathrm{C} \pm 4$ are typical (Hudson 1977; Tucker and Wright 1990; Hoefs 2004). The greater range of variability of $\delta^{13} \mathrm{C}$ and $\delta^{18} \mathrm{O}$ in red compared to grey parts of the clasts suggests postdepositional alteration of $\delta^{13} \mathrm{C}$ and $\delta^{18} \mathrm{O}$ towards lower values. Lower values of $\delta^{18} \mathrm{O}$ may be interpreted as an effect of diagenesis in the presence of meteoric waters, given that oxygen isotopes are relatively mobile during post-depositional alteration (Banner and Hanson 1990; Jacobsen and Kaufman 1999). The positive and significant correlation of $\delta^{13} \mathrm{C}$ and $\delta^{18} \mathrm{O}$ values in red parts of the Sobków clasts $(r=0.70)$ suggests that diagenetic processes influenced the isotopic composition of the calcium carbonate forming the clasts. Positive correlation between $\delta^{13} \mathrm{C}$ and $\delta^{18} \mathrm{O}$ values is a characteristic feature of diagenetic changes influenced by meteoric waters (Allan and Matthews 1982). In contrast, the lack of correlation between $\delta^{13} \mathrm{C}$ and $\delta^{18} \mathrm{O}$ values in the grey parts of the clasts $(r=0.10)$ may suggest the limited influence of diagenetic processes on changes in $\delta^{13} \mathrm{C}$ and $\delta^{18} \mathrm{O}$ isotope signatures in these parts of the clasts.

The problem of the origin of the lower part of the layer with bored and encrusted clasts is still not fully resolved. According to Chudzikiewicz and Wieczorek (1985), the



Fig. 8 Genesis and main features of bored and encrusted clasts and the layer with the clasts. Partly based on Chudzikiewicz and Wieczorek (1985) and Gruszczyński (1986), modified and supplemented 
accumulation of clasts which underwent a complex process prior to their final burial, points to a long period of formation. In their opinion, the layer thus formed was the result of gradual accumulation of clasts eroded from a hardground developing nearby. On the other hand, the sedimentary succession of the lower part of the layer permits the suggestion that it probably originated from gravity mass movement. Probably, seismic events associated with fault movements initiated mass movements along tectonically controlled scarps during Lower Platynota Zone time. The effects of such movements are observable in many other sites in central and southern Poland (e.g., Kutek 1968, 1994; Matyszkiewicz 1996; Krajewski et al. 2016). The sediment forming the lower part of the layer with bored clasts was deposited as a debris flow, conglomerate and in the higher part from turbidity current where normal grading is observed (Fig. 8). The upper part of the layer with grey clasts at the base (above erosional surface) represents early transgressive reworking to give coarser sediments at the base, fining up as water depth increased (Figs. 3, 4).

\section{Hardground in the Lowermost Marly Horizon as the Kim 1 sequence boundary}

The hardground and the base of the layer with bored and encrusted clasts is a sequence boundary between Kutek's (1994) intervals I and II (Figs. 2, 3a, b). Biostratigraphic data from the SW margin of the Holy Cross Mountains (e.g., Kutek 1968, 1994; Kutek et al. 1992; Matyja 2011) indicate that the sequence boundary correlates well with the third-order sequence boundary Kim 1 (Hardenbol et al. 1998). In the investigated succession from the Planula and Platynota zones, transgressive, highstand and lowstand systems tracts can be distinguished. The most significant events in these systems tracts are:

(i) drowning of the platform at the turn of the Planula and Platynota Zones and change in sedimentation from coral and oolitic facies to marl, as well as marly and fine-grained limestone and lime mudstone, all combining to form the Lowermost Marly Horizon;

(ii) sea-level fall, development of a hardground of regional extent and its brecciation and redeposition of the clasts;

(iii) development of the next sedimentary sequence representing interval II belonging to the Platynota-Hypselocyclum zones during the subsequent sea-level rise.

\section{Regional implications}

The succession of the Planula/Platynota Zones from the study area represents one of the most important stages in

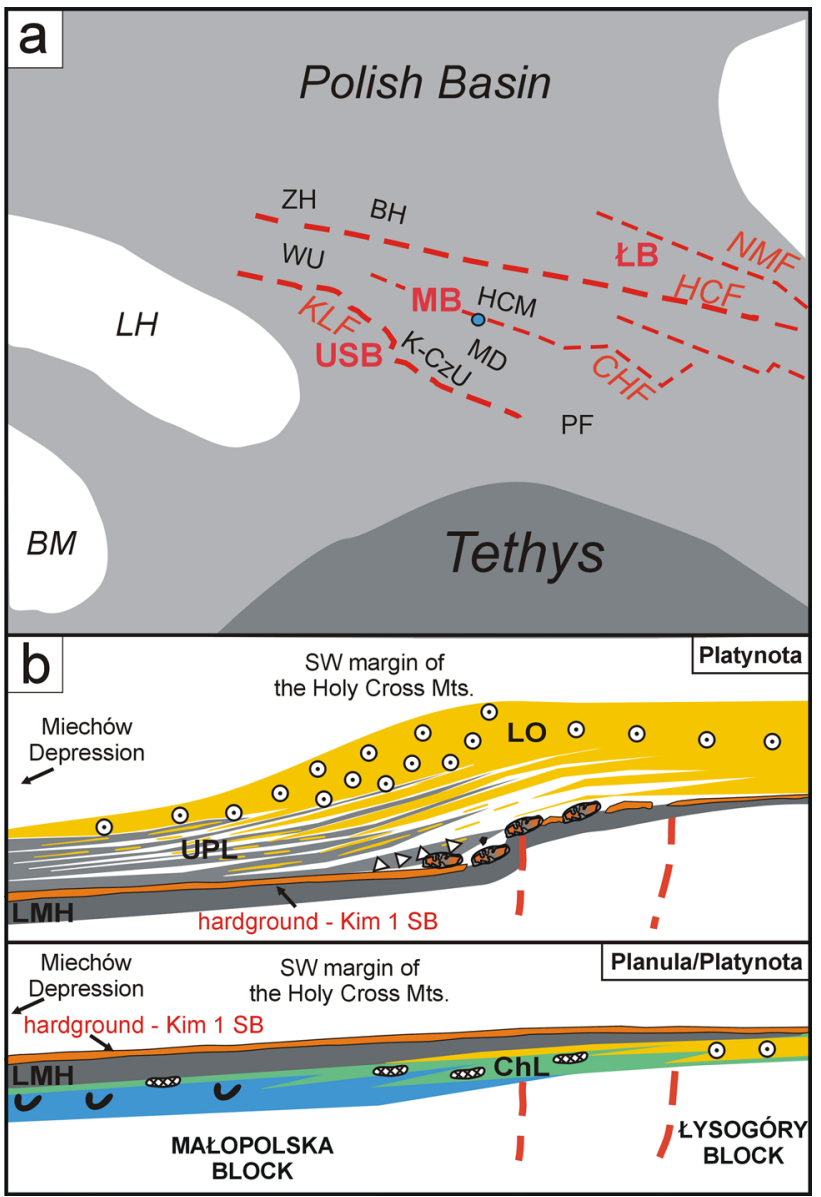

Fig. 9 Upper Jurassic paleogeographical position and facies distribution on the NE margin of the Małopolska Block (SW margin of the Mesozoic border of the Holy Cross Mountains). a Paleogeographical position of the study areas (after Ziegler 1990), modified and supplemented) and the position of main tectonic structures (in red): Małopolska Block (MB), Łysogóry Block (ŁB), Upper Silesian Block (USB). Red lines indicate main faults bordering the Małopolska Block: Holy Cross Fault (HCF), Kraków-Lubliniec Fault (KLF), Chmielnik Fault (CHF), Nowe Miasto Fault (NMF). Abbreviations in black indicate areas containing the discussed Upper Jurassic deposits: Złoczew High (ZH), Bełchatów High (BH), SW margin of the Holy Cross Mountains, (HCM), Wielun Upland (WU), Miechów Depression (MD), Kraków-Częstochowa Upland (KCU), Precarpathian Foredeep (PF). The blue dot indicates the approximate position of Sobków quarry. b Schematic cross-sections oriented transversally to the Małopolska Block showing the distribution of the Upper Oxfordian (Planula Zone) and Lower Kimmeridgian (Platynota Zone) facies on the main Paleozoic tectonic blocks. $L M H$ Lowermost Marly Horizon, UPL Underlying Pelitic Limestone, $L O$ Lower Oolite, $C h L$ Chalky Limestone. Descriptions as on Fig. 2

platform evolution, expressed by the cessation of shallowmarine sedimentation and replacement by marl and gravityflow deposits (Figs. 2, 9). Evaluation of the current state of knowledge about the Upper Oxfordian and Lower Kimmeridgian successions may lead to the discovery of significant implications, which will help with the understanding 
of deposition on the Polish part of the northern Tethys shelf. The Polish part of the platform is most commonly classified as a carbonate ramp or open shelf (e.g., Matyja et al. 1989; Kutek 1994; Gutowski et al. 2005; Krajewski et al. 2011a). Rapid sedimentation on the platform occurred during the Upper Transversarium-Bifurcatus and Planula Zones, when reef and biostrome facies became common (e.g., Matyszkiewicz et al. 2012, 2015, 2016; Krajewski et al. 2016). This may have been connected with the Middle Oxfordian (Transversarium Zone) warming of climate and sea-level rise (e.g., Price and Rogov 2009; Brigaud et al. 2014; Colombié et al. 2014; Wierzbowski 2015), which initiated the vast development of carbonate platforms across many European areas (e.g., Leinfelder et al. 1996; Matyszkiewicz 1997; Olóriz et al. 2003; Reolid et al. 2005; Bádenas and Aurell 2010; Olivier et al. 2011; Colombié et al. 2014). The sequence from central and southern Poland indicates that platform morphology and paleoenvironmental conditions were significantly modified during through extensional tectonic movements (Kutek 1994; Matyszkiewicz et al. 2006, 2012, 2016; Krajewski et al. 2014, 2016). In effect, a carbonate ramp underwent intermittent disintegration into many smaller fault-controlled intra-platform ridges and basins.

The block structure of the basement and synsedimentary tectonics influenced facies development on the platform (e.g., Kutek 1994; Matyszkiewicz et al. 2006; Złonkiewicz 2006; Krajewski et al. 2016). For example, in the Upper Oxfordian, the areas situated on uplifted intraplatform ridges (e.g., the Kraków-Częstochowa Upland, the SW margin of the Holy Cross Mts. and the Złoczew and Bełchatów highs), which simultaneously constituted the marginal parts of the main basement blocks (Fig. 9), were occupied by mid- and inner-platform microbial-sponge, microbial-Crescentiella, coral and oolitic facies (Krajewski et al. 2016). Deeper-water sponge-fine-grained limestone, lime mudstone, and marly facies were widely distributed, mainly in the central part of the Małopolska Block (e.g., Wieluń Upland, Miechów Depression, Precarpathian Foredeep), forming the intra-platform basin. As a result of progradation of shallow-water facies, the basins were successively filled with sediments, and the platform morphology underwent a gradual leveling up.

In the Transversarium-Platynota succession of central and southern Poland, three episodes related to synsedimentary tectonics can be distinguished; during these episodes, a pause in reef development occurred, gravity-flow deposits and neptunian dykes were commonly developed (e.g., Kutek 1968, 1994; Matyszkiewicz et al. 2006, 2012, 2016; Krajewski et al. 2014, 2016). These episodes may be correlated with the third-order Ox 5 (Transversarium Zone),
Ox 6 (Upper Bifurcatus Zone), and Kim 1 (Platynota Zone) sequence boundaries (Hardenbol et al. 1998). Another factor controlling Upper Oxfordian-Lower Kimmeridgian sedimentation was eustatic sea-level rises followed by the development of deep-water outer-platform marly and fine-grained-sponge facies, mainly during the Bimammatum Zone (e.g., Matyja et al. 1989; Matyja and Wierzbowski 2000; Krajewski et al. 2016). At the beginning of this zone, a distinct change occurred in the ammonite faunas. At known intervals, major migrations of ammonites of Boreal and Subboreal affinity took place. These migrations could have been caused by changes in ocean circulation during the sea-level highstand. These deposits are probably related to a maximum sea-level rise during the Bimammatum (Semimammatum and Hauffianum subzones; Hardenbol et al. 1998; Matyja and Wierzbowski 2000) and its boundary may be correlated with Ox 7 and Ox 8 sequence boundaries (Krajewski et al. 2016). Periodic changes in facies and platform morphology on the edges of tectonic blocks in central and southern Poland most probably took place in Callovian-Late Albian times (Kutek 1994) and were the main factor controlling the sedimentation on the $\mathrm{N}$ Tethys shelf. The opening of the Northern Atlantic and Tethys Oceans resulted in the Late Jurassic stress-field reorganization, which also included the passive, northern margin of the Tethys (e.g., Ziegler 1990; Allenbach 2001, 2002; Nieto et al. 2012), along with central and southern Poland. The Paleozoic faults were reactivated, which gave rise to pulses of subsidence and location of Late Jurassic depocenters over the Late Paleozoic grabens (e.g., Allenbach 2001, 2002; Wetzel et al. 2003; Krajewski et al. 2016; Matyszkiewicz et al. 2016). Siliciclastic input, especially at the turn of the Oxfordian and Kimmeridgian, was related to sea-level fall, synsedimentary tectonics, and/or more humid climatic conditions, which occurred in more northern European basins (e.g., Brigaud et al. 2014).

Periodic disintegration of the ramp into smaller paleogeographic elements occurred during the intervals of strong extensional tectonics that occurred both in the Carpathian area and in central and southern Poland (Kutek 1994). Sedimentation and facies architecture on the Polish part of the Tethys shelf may be related to the main paleogeographic elements (ridges and basins) described from the areas of the western Outer Carpathians (e.g., Golonka et al. 2005, 2008). The ridges and basins located at the boundary of the Upper Silesian, Małopolska, and Łysogóry blocks (Fig. 9) may have resulted from NE progradation of rifting from the southern areas into the northern Tethys shelf. These may constitute the NE continuation of parallel swells and basins in a NW-SE direction developed in the southern part of the platform (Peri-Tethys) adjacent to the Alpine Tethys. 


\section{Conclusions}

The integrated microfacies analysis, taphonomical, ichnological, and geochemical results, along with comparisons with other sections from southern Poland placed in a stratigraphic context, have provided the following conclusions:

1. The Lower Kimmeridgian (Platynota Zone) regional hardground from Sobków quarry is a sequence boundary between the distinct Upper Oxfordian and Lower Kimmeridgian stages of platform evolution. It correlates well with the third-order sequence boundary Kim 1 .

2. The hardground was eroded in some areas of central Poland and is now preserved as bored and encrusted clasts. The preserved borings and encrusters represent time-averaged assemblages comprising several generations of organisms that colonized the clasts at different times and in different environments (in terms of depth) during their pre-final-burial history. The composition of the borings may indicate, however, that colonization of the clasts generally proceeded in a shallow-water environment in which the hydrodynamics were strong enough to overturn the clasts. The overall low level of diversity of clastencrusting organisms may have been the result of the unstable conditions governing their development such as the overturning clasts and fluctuations in salinity.

3. The clasts were reworking on an oxygenated seafloor in extremely shallow water environment, which resulted in pyrite oxidation and their red coloration. The higher variability of $\delta^{13} \mathrm{C}$ and $\delta^{18} \mathrm{O}$ in red parts compared to grey parts of the clasts reflect stronger diagenetic changes within red parts of the clasts. Prior to final burial, the clasts were subjected to burial, submarine exhumation, redeposition and recolonization by further boring and encrusting organisms. Final redeposition and burial of the clasts were related to debris flow. The sediment redeposition during the Lower Platynota Zone was probably connected with seismic events along reactivated faults.

4. Comparison the Middle Oxfordian-Lower Kimmeridgian strata from central and southern Poland indicates that the platform morphology and paleoenvironmental conditions were periodically subjected to significant modification during phases of extensional tectonic movements. In effect, the carbonate ramp underwent intermittent disintegration into smaller, fault-controlled intra-platform ridges and basins. Those located at the boundary of terranes may have resulted from north-eastern progradation of rifting from the southern areas into the northern Tethys shelf. These may constitute the NE continuation of parallel swells and basins in a NW-SE direction developed in the southern part of the carbonate platform adjacent to the Alpine Tethys.

Acknowledgements We thank the Institute of Geological Sciences of the Polish Academy of Sciences in Kraków, for the possibility to study the collection with bored and encrusted clasts. Sincere thanks to L. Chudzikiewicz for archival photographs from Sobków quarry. The authors are grateful to the two reviewers, M. Wilson and an anonymous reviewer, and to the editor $M$. Tucker for their constructive comments and suggestions that considerably improved this paper. The research was financed from the AGH-UST Grant Nos. 11.11.140.626 and 15.11.140.820.

Open Access This article is distributed under the terms of the Creative Commons Attribution 4.0 International License (http://creativecommons.org/licenses/by/4.0/), which permits unrestricted use, distribution, and reproduction in any medium, provided you give appropriate credit to the original author(s) and the source, provide a link to the Creative Commons license, and indicate if changes were made.

\section{References}

Allan JR, Matthews RK (1982) Isotope signatures associated with early meteoric diagenesis. Sedimentology 29:797-817

Allenbach RP (2001) Synsedimentary tectonics in an epicontinental sea: a new interpretation of the Oxfordian basin of northern Switzerland. Eclogae Geol Helv 94:265-287

Allenbach RP (2002) The ups and downs of 'Tectonic Quiescence'recognizing differential subsidence in the epicontinental sea in the Oxfordian in the Swiss Jura Mountains. Sediment Geol 150:323-342

Anketell JM, Cegła J, Dżułyński S (1970) On the deformational structures in systems with reversed density gradients. Ann Soc Geol Polon 40:1-30

Bádenas B, Aurell M (2010) Facies models of a shallow-water carbonate ramp based on distribution of non-skeletal grains (Kimmeridgian, Spain). Facies 56:89-110

Banner JL, Hanson GN (1990) Calculation of simultaneous isotopic and trace element variations during water-rock interaction with applications to carbonate diagenesis. Geochim Cosmochim Acta 54:3123-3137

Brigaud B, Vincent B, Carpentier C, Robin C, Guillocheau F, Yven B, Huret E (2014) Growth and demise of the Jurassic carbonate platform in the intracratonic Paris Basin (France): interplay of climate change, eustasy and tectonics. Mar Petrol Geol 53:3-29

Bromley RG (1994) The palaeoecology of bioerosion. In: Donovan SK (ed) The palaeobiology of trace fossils. Wiley, Chichester, pp 134-154

Bromley RG (2004) A stratigraphy of bioerosion. In: McIlroy D (ed) The application of ichnology to palaeoenvironmental and stratigraphic analysis: geological society. London, Special Publications 228, pp 455-479

Chudzikiewicz L, Wieczorek J (1985) Bored and encrusted clasts in the Lower Kimmeridgian carbonates at Sobków (SW margin of the Holy Cross Mts., Poland). Ann Soc Geol Polon 55:295-306

Colombié C, Giraudb F, Schnyder J, Götz AE, Boussaha M, Aurell M, Bádenas B (2014) Timing of sea level, tectonics and climate 
events during the uppermost Oxfordian (Planula zone) on the Iberian ramp (northeast Spain). Palaeogeogr Palaeoclimatol Palaeoecol 412:17-31

Fürsich FT (1979) Genesis, environments, and ecology of Jurassic hardgrounds. N Jahrb Geol Pal Abh 158:1-63

Fürsich FT, Palmer TJ, Goodyear KL (1994) Growth and disintegration of bivalve-dominated patch reefs in the Upper Jurassic of southern England. Palaeontology 37:131-171

Goldring R, Kaźmierczak J (1974) Ecological succession in intraformational hardground formation. Palaeontology 17:949-962

Golonka J, Gahan L, Krobicki M, Marko F, Oszczypko N, Ślączka A (2005) Plate tectonic evolution and paleogeography of the circum-Carpathian region. In: Golonka J, Picha FF (eds) The Carpathians and their foreland: geology and hydrocarbon resources. American Association of Petroleum Geologists, Memoir 84, pp $11-46$

Golonka J, Krobicki M, Waśkowska-Oliwa A, Vašíček Z, Skupien P (2008) Main paleogeographical elements of the West Outer Carpathians during Late Jurassic and Early Cretaceous times. Geologia 34:61-72

Gruszczyński M (1986) Hardgrounds and ecological succession in the light of early diagenesis (Jurassic, Holy Cross Mts., Poland). Acta Palaeon Polon 31:163-212

Gutowski J, Popadyuk IV, Olszewska B (2005) Late Jurassic-earliest Cretaceous evolution of the epicontinental sedimentary basin of southeastern Poland and western Ukraine. Geol Quart 49:31-44

Hardenbol J, Thierry J, Farley MB, Jacquin T, de Graciansky PC, Vail PR (1998) Jurassic chronostratigraphy. In: de Graciansky PC, Hardenbol J, Jacquin T, Vail PR (eds) Mesozoic and Cenozoic sequence stratigraphy of European basin. SEPM Spec Pub, 60

Hoefs J (2004) Stable isotope geochemistry, 5th edn. Springer, Berlin

Hudson JD (1977) Stable isotopes and limestone lithification. J Geol Soc Lond 133:637-660

Jacobsen SB, Kaufman AJ (1999) The Sr, C and O isotopic evolution of Neoproterozoic seawater. Chem Geol 161:37-57

Jurkowska A (2016) Inoceramid stratigraphy and depositional architecture of the Campanian and Maastrichtian of the Miechów Synclinorium (southern Poland). Acta Geol Polon 66:59-84

Kaźmierczak J, Pszczółkowski A (1968) Synsedimentary discontinuities in the Lower Kimmeridgian of the Holy Cross Mts. Acta Geol Pol 18:587-612

Kelly SRA, Bromley RG (1984) Ichnological nomenclature of clavate borings. Palaeontology 27:793-807

Krajewski M, Matyszkiewicz J, Król K, Olszewska B (2011a) Facies of the Upper Jurassic-Lower Cretaceous deposits from the southern part of the Carpathian Foredeep basement in the Kraków-Rzeszów area (southern Poland). Ann Soc Geol Polon 81:269-290

Krajewski M, Król K, Olszewska B, Felisiak I, Skwarczek M (2011b) Facies of the Upper Jurassic-Lower Cretaceous sediments in the basement of the Carpathian Foredeep (western Ukraine). Ann Soc Geol Polon 81:291-307

Krajewski M, Olchowy P, Felisiak I (2014) Lower Kimmeridgian layer with bored and encrusted hiatus concretions (Upper Jurassic, central Poland): implications for stratigraphy and basin evolution. Ann Soc Geol Polon 84:113-129

Krajewski M, Olchowy P, Felisiak I (2016) Late Jurassic facies architecturev of the Złoczew Graben: implications for evolution of the tectonic-controlled northern peri-Tethyan shelf (Upper Oxfordian-Lower Kimmeridgian, Poland). Facies 62:4

Kutek J (1968) The Kimmeridgian and Uppermost Oxfordian in the SW margins of the Holy Cross Mts., (central Poland): Part Istratigraphy. Acta Geol Polon 18:493-587 (in Polish with English Summary)
Kutek J (1969) The Kimmeridgian and Uppermost Oxfordian in the SW margins of the Holy Cross Mts., (central Poland): Part IIPaleogeography. Acta Geol Polon 19:221-322 (in Polish with English Summary)

Kutek J (1994) Jurassic tectonic events in south-eastern Poland. Acta Geol Polon 44:167-221

Kutek J, Matyja BA, Wierzbowski A (1992) The Holy Cross Mountains, introduction. In: Matyja BA, Wierzbowski A, Radwański A (eds) Oxfordian and Kimmeridgian Joint Working Groups Meeting, Guide Book and Abstracts, September 7-12. Warsaw, pp 22-26

Leinfelder RR, Werner W, Nose M, Schmid DU, Krautter M, Laternser R, Takacs M, Hartmann D (1996) Paleoecology, growth parameters and dynamics of coral, sponge and microbolite reefs from the Late Jurassic. Göttinger Arb Geol Paläont Sb 2:227-248

Lescinsky HL, Edinger E, Risk MJ (2002) Mollusc shell encrustation and bioerosion rates in a modern epeiric sea: Taphonomy of experiments in the Java Sea, Indonesia. Palaios 17:171-191

Machalski M (1998) Oyster life positions and shell beds from the Upper Jurassic of Poland. Acta Palaeon Polon 43:609-634

Matyja BA (2011) Płytkowodna platforma wêglanowa późnej Jury na południowo-zachodnim obrzeżeniu Gór Świętokrzyskichmateriały do sesji terenowych. Materiały Konferencyjne Jurassica IX, Małogoszcz, 06-08 września 2011. In: Polskie Towarzystwo Geologiczne, Polska Grupa Robocza Systemu Jurajskiego, pp. 133-151 (in Polish)

Matyja BA, Wierzbowski A (2000) Biological response of ammonites to changing environmental conditions: an example of Boreal Amoeboceras invasions into Submediterranean Province during Late Oxfordian. Acta Geol Polon 50:45-54

Matyja BA, Gutowski J, Wierzbowski A (1989) The open shelfcarbonate platform succession at the Oxfordian/Kimmeridgian boundary in the SW margin of the Holy Cross Mts: stratigraphy, facies and ecological implications. Acta Geol Pol 39:29-48

Matyszkiewicz J (1996) The significance of Saccocoma-calciturbidites for the analysis of the Polish Epicontinental Late Jurassic Basin: an example from the Southern Cracow-Wielun Upland (Poland). Facies 34:23-40

Matyszkiewicz J (1997) Microfacies, sedimentation and some aspects of diagenesis of Upper Jurassic sediments from the elevated part of the Northern peri-Tethyan Shelf: a comparative study on the Lochen area (Schwäbische Alb) and the Cracow area (CracowWielun Upland, Poland). Berliner Geo Abh E 21:1-111

Matyszkiewicz J, Krajewski M, Kędzierski J (2006) Origin and evolution of an Upper Jurassic complex of carbonate buildups from Zegarowe Rocks (Kraków-Wieluń Upland, Poland). Facies $52: 249-263$

Matyszkiewicz J, Kochman A, Duś A (2012) Influence of local sedimentary conditions on development of microbialites in the Oxfordian carbonate buildups from the southern part of the Kraków-Częstochowa Upland (south Poland). Sed Geol 263-264:109-132

Matyszkiewicz J, Kochman A, Rzepa G, Gołębiowska B, Krajewski M, Gajdzik K, Żaba J (2015) Epigenetic silicification of the Upper Oxfordian limestone in the Sokole Hills (KrakówCzęstochowa Upland): relationship to facies development and tectonics. Acta Geol Polon 65:181-203

Matyszkiewicz J, Krajewski M, Kochman A, Kozłowski A, Duliński M (2016) Oxfordian neptunian dykes with brachiopods from the southern part of the Kraków-Częstochowa Upland (southern Poland) and their links to hydrothermal vents. Facies 62:12

Montenat Ch, Barrier P, Ott d'Estevou P, Hibsch Ch (2007) Seismites: an attempt at critical analysis and classification. Sediment Geol 196:5-30 
Nieto LM, Reolid M, Molina JM, Ruiz-Ortiz PA, Jiménez-Millán J, Rey J (2012) Evolution of pelagic swells from hardground analysis (Bathonian-Oxfordian, Eastern External Subbetic, southern Spain). Facies 58:389-414

Olivier N, Colombié C, Pittet B, Lathuiličre B (2011) Microbial carbonates and corals on the marginal French Jura platform (Late Oxfordian, Molinges section). Facies 57:469-492

Olóriz F, Reolid M, Rodríguez-Tovarm FJ (2003) A Late Jurassic carbonate ramp colonized by sponges and benthic microbial communities (External Prebetic, southern Spain). Palaios $18: 428-545$

Palmer TJ, Fürsich FT (1974) The ecology of a Middle Jurassic hardground and crevice fauna. Palaeontology 17:507-524

Pemberton SG, Kobluk DR, Yeo RK, Risk MJ (1980) The boring Trypanites at the Silurian-Devonian disconformity in southern Ontario. J Paleontol 54:1258-1266

Pożaryski W, Brochwicz-Lewiński W, Brodowicz Z, JaśkowiakSchoeneichowa M, Milewicz J, Sawicki L, Uberna T (1979) Geological map of Poland and adjoining countries without Cenozoic formations 1:1,000,000. Geol Inst, Warszawa (in Polish)

Price GD, Rogov MA (2009) An isotopic appraisal of the Late Jurassic greeenhouse phase in the Russian Platform. Palaeogeogr Palaeoclimatol Palaeoecol 273:41-49

Radwańska U (2004) Tube-dwelling polychaetes from the Upper Oxfordian of Wapienno/Bielawy, Couiavia region, north-central Poland. Acta Geol Polon 54:35-52

Radwański A (2003) Rezidualne brykiety kolapsyjne w pakietach margli górnego kimerydu Małogoszcza. Tomy Jurajskie 1:77-83 (in Polish)

Reolid M, Gaillard Ch, Olóriz F, Rodríguez-Tovar FJ (2005) Microbial encrustations from the Middle Oxfordian-earliest Kimmeridgian lithofacies in the Prebetic Zone (Betic Cordillera, southern Spain): characterization, distribution and controlling factors. Facies 50:529-543

Retallack GJ (2001) Soils of the past: an introduction to paleopedology, 2nd edn. Blackwell Science Ltd, Oxford, p 600

Taylor PD (1979) Palaeoecology of the encrusting epifauna of some British Jurassic bivalves. Palaeogeogr Palaeoclimatol Palaeoecol 28:241-262

Taylor PD, Wilson MA (2002) A new terminology for marine organisms inhabiting hard substrates. Palaios 17:522-525

Taylor PD, Wilson MA (2003) Palaeoecology and evolution of marine hard substrate communities. Earth Sci Rev 62:1-103

Tucker ME, Wright VP (1990) Carbonate sedimentology. Blackwell Scientific, Oxford, p 482
Wetzel A, Allenbach R, Allia V (2003) Reactivated basement structures affecting the sedimentary facies in a tectonically "quiescent" epicontinental basin: an example from NW Switzerland. Sediment Geol 157:153-172

Wierzbowski H (2015) Seawater temperatures and carbon isotope variations in central European basins at the Middle-Late Jurassic transition (Late Callovian-Early Kimmeridgian). Palaeogeogr Palaeoclimatol Palaeoecol 440:506-523

Wilson MA (1985) Disturbance and ecologic succession in an Upper Ordovician cobble-dwelling hardground fauna. Science 228:575-577

Wilson MA (1987) Ecological dynamics on pebbles, cobbles, and boulders. Palaios 2:594-599

Wilson MA, Palmer TJ (1994) A carbonate hardground in the Carmel Formation (Middle Jurassic, SW Utah, USA) and its associated encrusters, borers and nestlers. Ichnos 3:79-87

Wilson MA, Feldman HR, Krivicich EB (2010) Bioerosion in an equatorial Middle Jurassic coral-sponge reef community (Callovian, Matmor Formation, southern Israel). Palaeogeogr Palaeoclimatol Palaeoecol 289:93-101

Wilson MA, Zatoń M, Avni Y (2012) Origin, palaeoecology and stratigraphic significance of bored and encrusted concretions from the Upper Cretaceous (Santonian) of southern Israel. Palaeobiodivers Palaeoenviron 92:343-352

Zatoń M, Machalski M (2013) Oyster-microbial rolling stones from the Upper Jurassic (Kimmeridgian) of Poland. Palaios 28:839-850

Zatoń M, Machocka S, Wilson MA, Marynowski L, Taylor PD (2011a) Origin and paleoecology of Middle Jurassic hiatus concretions from Poland. Facies 57:275-300

Zatoń M, Wilson MA, Zavar E (2011b) Diverse sclerozoan assemblages encrusting large bivalve shells from the Callovian (Middle Jurassic) of southern Poland. Palaeogeogr Palaeoclimatol Palaeoecol 307:232-244

Żelaźniewicz A, Aleksandrowski P, Buła Z, Karnkowski PH, Konon A, Oszczypko N, Ślączka A, Żaba J, Żytko K (2011) Regionalizacja tektoniczna Polski. Komitet Nauk Geologicznych PAN, Wrocław (in Polish)

Ziegler PA (1990) Geological Atlas of Western and Central Europe. Shell Intern Petrol Maatsch BV The Hague, pp $239+56$ enclosures

Złonkiewicz Z (2006) Evolution of the Miechów Depression basin in the Jurassic as a result of regional tectonical changes. Geol Rev 54:534-540 (in Polish with English Summary) 